\title{
Osteoporosis in steroid-dependent asthma patients in Mosul
}

\author{
Talal M. Al-Saegh", Dhaher J. S. Al-Habbo**, Miss Muna M. Ahmad ${ }^{* * *}$, Wadhah M. Hammo**** \\ * Specialist in Medicine, Ibn Sena Teaching Hospital; **Department of Medicine, ${ }^{* \star \star}$ Department of Community \\ Medicine, College of Medicine, University of Mosul; ${ }^{* \star \star \star R a d i o l o g i s t, ~ I b n s e n a ~ T e a c h i n g ~ H o s p i t a l . ~}$
}

(Ann. Coll. Med. Mosul 2012; 38 (2): 80-86).

Received: $20^{\text {th }}$ Jul. 2011; Accepted: $9^{\text {th }}$ Jul. 2012.

\section{ABSTRACT}

Objectives: To examine the prevalence of osteoporosis in steroid dependent asthma. To compare it with non-asthmatic patients who use steroid for different diseases and with a third group of patients who were referred for dual-energy X-ray absorptiometry (DXA) for various complaints and they never used steroid.

Patients and methods: The study involved 70 asthma patients (12 males and 58 females) on oral corticosteroids and /or inhaled steroid, with their mean age of 48.94 with $S D \pm 13.49,40$ non asthmatic patients ( 3 males and 37 females) on oral steroid with their mean age of 53.93 with SD \pm 13.02 and 47 patients as control one male and 46 females who are neither asthmatic nor using steroids, their mean age of 52.47 with $\mathrm{SD} \pm 9.76$. All patients and controls were studied in the outpatient department in Ibn Sena Teaching Hospital. All patients and controls had their bone mineral density (BMD) measurement done by using dual-energy $x$-ray absorptiometry (DXA).

Results: The effects of weight on the development of osteopenia or osteoporosis indicate no statistically significant effects on the development of osteopenia or osteoporosis. The doses of steroids in osteoporotics showed no statistically significant difference between asthmatics and non-asthmatics. In osteopenia in both groups indicates statistically significant differences between them in favour of asthmatics over nonasthmatics. The duration of treatment with steroids for asthmatics and non-asthmatics indicates that, in osteoporotics asthmatics and non-asthmatics there were statistically significant difference between them, in favour of asthmatics over non-asthmatics, so as in osteopenics. Patients with asthma who take inhaled steroid only, indicates that the higher dose of inhaled steroids lead to osteoporosis with statistically significant difference between those who developed osteopenia or osteoporosis.

We compared the DEXA scan score values (T-scores and Z-score values) of asthmatics and nonasthmatics in the entire sample in this study. There were statistically significant differences between asthmatics and non-asthmatics (including the controls) with $p$-value for the T-scores and Z-score of $(0.000,0.000)$ respectively.

Conclusion: asthma should be regarded as independent risk factor for the development of osteopenia and osteoporosis. Steroid dose should be monitored. Adequate vitamin D supplement as preventive measures is well recognized factor in osteoporosis and osteopenia of all causes.

Keywords: Asthma, osteoporosis, steroids, DXA.

الأهداف: دراسة نسبة حدوث هشانشة وتتخر العظام عند مرضى الربو القصبي المعتمدين في علاجهم على الكورتيزون ومقارنتهم

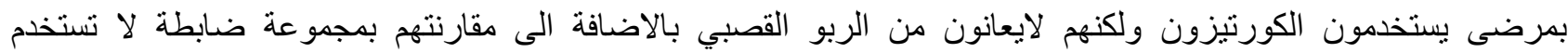
الكورنيزون.

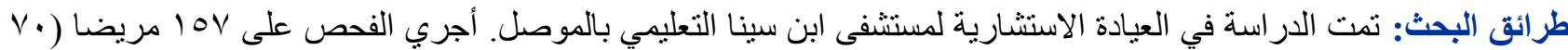

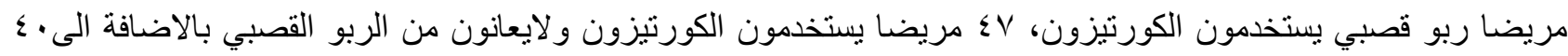
مريضا كمجمو عة ضابطة). أجري لجميع العينة فحص هشانشة العظام (DXA). 


$$
\text { النتائج: وزن المرضى لم يكن له تأثير معنوي يفرق بين مرضى الربو القصبي و المرضى الآخرين. }
$$

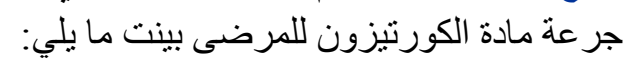

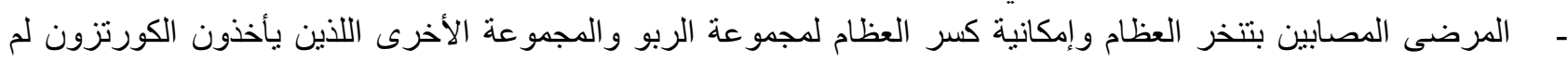

$$
\text { تسجل فروقات معنوية بينهم. }
$$

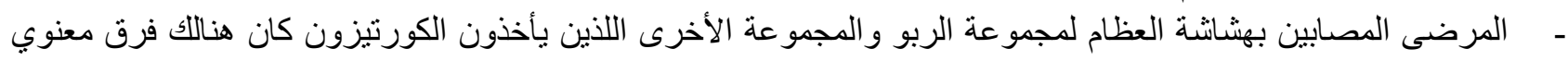

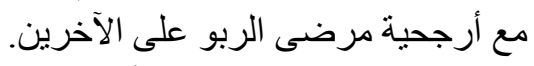

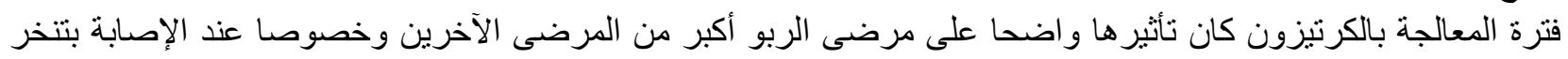

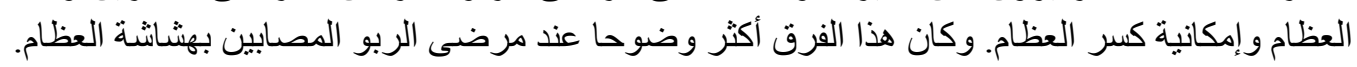

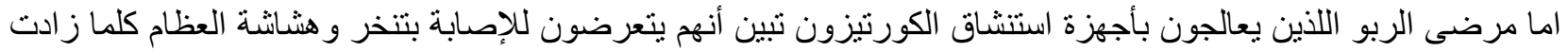

جر عة العلاج او الفترة الزمنية.

عند دراسة قيمة ( T-score \& Z-score) لمرضى الربو القصبي والمرضى الآخرين ظهر ان هناللك فرق معنوي كبير يرجح مضى الربو عن بقية العينة المفحوصة.

الاستنتاج: مما تقدم نستطيع القول بان الربو القينة القصبي بحد ذاته مسبب رئيسي للإصابة بنخر ولهثاشة العظام. ويجب إعطاء المرضى فيتامين D3 و الكالسيو كعلاج وقانئي.

O steoporosis occurs when the normal processes of bone formation and resorption are no longer coupled, leading to a net loss of bone and thus to an increased risk of fracture ${ }^{(1)}$.

Osteoporosis is diagnosed by measuring bone mineral density (BMD) using dual-energy $x$-ray absorptiometry (DXA). According to the World Health Organization, osteopenia is defined as BMD between 1 and 2.5 standard deviations (SDs) below that of young adults ( $T$ score $\leq-2.5$ ); osteoporosis is defined as BMD $>2.5 \mathrm{SDs}$; BMD measurements obtained in this manner reflects bone mineral content as well as the size of the bone.

Bone strength is determined by collagenous proteins (tensile strength) and mineralized osteoid (compressive strength) ${ }^{(1)}$ the higher the concentration of calcium, the greater the compressive strength.

The time and duration of steroid therapy and the time of asthma had influence on the degree of osteoporosis. Moderate development of osteoporosis is probably the result of even low dose of steroid ${ }^{(2)}$.

Accumulating evidence suggests that the effect of inhaled corticosteroids on bone is not small. Recent studies have shown that long-term use of inhaled corticosteroid at moderate or high doses is also associated with increased risk on bone ${ }^{(3)}$.

New research indicates that men with chronic lung disease who use long-term corticosteroid therapy face a nine fold rise in the risk of osteoporosis; among those who do not use corticosteroids, that risk is increased fivefold only ${ }^{(3)}$.

lqbal and colleagues ${ }^{(4)}$ found a surprisingly high increase in the risk of osteoporosis in men with chronic lung disease having an almost identical burden of disease as do postmenopausal women age 60 to 90 years. Furthermore, he found that all of men with chronic lung disease lost bone mass, regardless of whether they were taking corticosteroids or not, which indicates that lung disease, is an independent risk factor for osteoporosis.

The aims of the study are to test the prevalence of osteoporosis in steroid dependant asthma and to compare them with non-asthmatics that use steroids for different reasons with controlled group. The effect of weight on the development of osteopenia or osteoporosis was analyzed. Furthermore, to consider the possibility of using prophylaxis therapy in steroid dependent asthma to prevent or halt the development of osteoporosis.

\section{PATIENTS AND METHODS}

This study involved 157 patients, 70 asthma patients (12 males and 58 females) on oral corticosteroids and / or inhaled steroid (i.e. prednisolone as oral steroid and beclomethazone for inhaled steroid), 40 non-asthmatic patients (3 males and 37 females) on oral steroid and 47 
patients as control one male and 46 females who are neither asthmatic nor using steroids; their mean ages were $48.9 \pm 13.5,53.9 \pm 13.0$ and $52.5 \pm$ 9.8 years respectively. All patients and controls were studied in the outpatient department, in the respiratory clinic and x-ray department in Ibn Sena Teaching Hospital. All patients and controls had their bone mineral density (BMD) measurement done by using dual-energy $\mathrm{x}$-ray absorptiometry (DXA), in the x-ray department in Ibn Sena Teaching Hospital Medical Outpatient Clinic.

The verbal consent of all the patients and controls were taken beforehand, Dual-energy $x$-ray absorptiometry was part of their required follow up investigations during their consultation to the outpatient's clinic.

The inclusion criteria for the patients and controls were as follows; patients with asthma were diagnosed clinically and by lung function test as asthma. All were steroid dependent asthmatics for long time and were on oral corticosteroids alone or plus inhaled corticosteroids, or on inhaled corticosteroids only. All the controlled group were not using any type of steroid and they consult the Dual-energy $x$-ray absorptiometry (DXA) unit and were not suffering from any disease which may cause osteoporosis.

The non-asthmatic patients who were on oral corticosteroids and were randomly selected from patients with (locomotor and connective tissue diseases, Skin and subcutaneous tissue diseases nervous system diseases, digestive system diseases and few circulatory system diseases) and were referred to the dual-energy $x$-ray absorptiometry (DXA) unit for follow-up. Patients with diseases which can lead to osteoporosis as a natural course of the disease were excluded from the study, like genetic (congenital) causes of osteoporosis, hypogonadal states that can cause osteoporosis, endocrine disorders that can cause osteoporosis and inflammatory diseases that can cause osteoporosis. Patients on medications known to cause or accelerate bone loss apart from corticosteroids were excluded from the study.

For the entire studied group DXA, of the spine (lateral) and hip radius were performed. As DXA is not expensive and it will only take up to 5-10 minutes to perform. DXA is currently the criterion standard for the evaluation of BMD because of its low cost, great precision, radiation exposure is kept to a minimum and it can be done on an

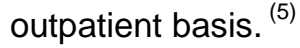

All the data from DXA were reported as T-scores and Z-scores. The T-score is the value compared to control subjects who are at their peak BMD, whereas the Z-score reflects a value compared to patients matched for age and sex, Z-scores some time used in premenopausal women and younger men with other parameter to assess osteoporosis. ${ }^{(6)}$

\section{RESULTS}

The effect of weight on the development of osteopenia or osteoporosis was studied for the three groups according to the mean of their weight in kilograms, standard deviation and the calculation of the P-values, all indicate that there was no statistically significant effect of the weight of the patients on the development of osteopenia or osteoporosis as seen in Table 1.

The doses of steroids were divided into three groups from the lower ( $<14 \mathrm{mg} /$ day) to the higher dose (>16 mg/day) as in Table 2, the effects of the doses of steroid on the development of osteopenia or osteoporosis in asthmatics and non-asthmatics studied. The results as seen in Table 2 show that for those who developed osteoporosis and liability to fracture of their bones there were no statistically significant difference between the two groups. However the results of those who developed osteopenia in both groups indicate a statistically significant difference between them especially among those in the smaller doses group in favour of asthmatics over non-asthmatics with $p$-value of (0.004) and this suggests that asthma per se may add to the factors which increase the liability of the development of osteopenia.

To evaluate the effect of the lower dose of steroid in asthmatic and non-asthmatic the odd ratio and the 95\% confidence interval were calculated as in Table $\mathbf{2 b}$, which confirms our previous allegation and indicates that (By comparing the effect of smaller dose with moderate and large dose of steroid) asthmatics were four times prone to develop osteopenia than non-astmatics. Furthermore, by increasing the dosage of steroid the risk increased ten times as the odd equals 9.5 . 
Table 1. The Mean of the weight of patients in $\mathrm{kg}$ with osteopenea or ostioporosis among the studied group.

\begin{tabular}{|l|c|c|c|c|}
\hline \multicolumn{1}{|c|}{ Type of patients } & $\begin{array}{c}\text { Osteoporosis with } \\
\text { liability to fracture } \\
\text { (Mean and SD) }\end{array}$ & $\begin{array}{c}\text { Osteopenia } \\
\text { (Mean and SD) }\end{array}$ & $\begin{array}{c}\text { Normal } \\
\text { (Mean and SD) }\end{array}$ & P-value \\
\hline Asthmatics & $\begin{array}{c}72.95 \pm(12.5) \\
\mathrm{n}=21\end{array}$ & $\begin{array}{c}78.59 \pm(19.43) \\
\mathrm{n}=32\end{array}$ & $\begin{array}{c}77.82 \pm(8.25) \\
\mathrm{n}=17\end{array}$ & 0.408 \\
\hline Non-asthmatics & $\begin{array}{c}62.4 \pm(16.12) \\
\mathrm{n}=10\end{array}$ & $\begin{array}{c}76.89 \pm(15.1) \\
\mathrm{n}=19\end{array}$ & $\begin{array}{c}71.55 \pm(11.04) \\
\mathrm{n}=11\end{array}$ & 0.047 \\
\hline Controls & & $\begin{array}{c}77.67 \pm(11.02) \\
\mathrm{n}=3\end{array}$ & $\begin{array}{c}77.52 \pm(14.03) \\
\mathrm{n}=44\end{array}$ & 0.986 \\
\hline
\end{tabular}

Table 2a. Patients on oral steroid with osteopenia or osteoporosis in relation the doses of steroid as mg of prednisolone.

\begin{tabular}{|l|c|c|c|c|c|c|}
\hline $\begin{array}{c}\text { Dose of steroid } \\
\text { in (mg:day) }\end{array}$ & $\begin{array}{c}\text { Asthmatics } \\
\text { Osteoporotic } \\
\text { No. (\%) }\end{array}$ & $\begin{array}{c}\text { Non-asthmatics } \\
\text { Osteoporotic } \\
\text { No. }(\%)\end{array}$ & $\begin{array}{c}\text { P- } \\
\text { value }\end{array}$ & $\begin{array}{c}\text { Asthmatics } \\
\text { Osteopenia } \\
\text { No. }(\%)\end{array}$ & $\begin{array}{c}\text { Non-asthmatics } \\
\text { Osteopenia } \\
\text { No. (\%) }\end{array}$ & $\begin{array}{c}\text { P- } \\
\text { value }\end{array}$ \\
\hline$<14 \mathrm{mg} /$ day & $3(15.8)$ & $2(20.0)$ & 0.576 & $5(17.9)$ & $11(57.90$ & 0.004 \\
\hline $14-16 \mathrm{mg} /$ day & $9(47.4)$ & $2(20.0)$ & 0.149 & $10(35.7)$ & $5(26.3)$ & 0.498 \\
\hline$>16 \mathrm{mg} /$ day & $7(36.8)$ & $6(60.0)$ & 0.212 & $13(46.4)$ & $3(15.8)$ & 0.030 \\
\hline Total & $19(100.0)$ & $10(100.0)$ & 0.342 & $28(100.0)$ & $19(100.0)$ & 0.012 \\
\hline
\end{tabular}

Table $2 \mathrm{~b}$. Patients on oral steroid with osteopenia or osteoporosis in relation the doses of steroid as mg of prednisolone.

\begin{tabular}{|c|c|c|c|c|c|c|c|c|}
\hline $\begin{array}{l}\text { Dose of } \\
\text { steroid in } \\
\text { (mg:day) }\end{array}$ & $\begin{array}{c}\text { Asthmatics } \\
\text { Osteoporotic } \\
\text { No. (\%) }\end{array}$ & $\begin{array}{c}\text { Non } \\
\text { Asthmatics } \\
\text { Osteoporotic } \\
\text { No. (\%) }\end{array}$ & $\begin{array}{l}\text { Odd } \\
\text { ratio }\end{array}$ & 兽 & $\begin{array}{c}\text { Asthmatics } \\
\text { Osteopenia } \\
\text { No. (\%) }\end{array}$ & $\begin{array}{c}\text { Non } \\
\text { Asthmatics } \\
\text { Osteopenia } \\
\text { No. (\%) }\end{array}$ & $\begin{array}{l}\text { Odd } \\
\text { ratio }\end{array}$ & 畩 \\
\hline$<14 \mathrm{mg} / \mathrm{day}^{*}$ & & & ...... & & & & $\ldots$ & $\cdots$ \\
\hline $\begin{array}{c}14-16 \\
\mathrm{mg} / \text { day }\end{array}$ & $9(47.4)$ & $2(20.0)$ & 3 & $\begin{array}{l}0.28- \\
31.6\end{array}$ & $10(35.7)$ & $5(26.3)$ & 4.4 & $\begin{array}{l}1.0- \\
19.8\end{array}$ \\
\hline$>16 \mathrm{mg} / \mathrm{day}$ & $7(36.8)$ & $6(60.0)$ & 0.718 & $\begin{array}{l}0.9- \\
6.32 \\
\end{array}$ & $13(46.4)$ & $3(15.8)$ & 9.5 & $\begin{array}{l}1.8- \\
4.9\end{array}$ \\
\hline Total & $19(100.0)$ & $10(100.0)$ & & & $28(100.0)$ & $19(100.0)$ & & \\
\hline
\end{tabular}

*reference group (low risk).

The duration of treatment with steroids for asthmatic and non-asthmatic patients were divided into three groups as seen in Table 3 starting from 10 years duration and ending in equal or more than 15 years. The analysis of these data shows that for those who developed osteoporosis among asthmatics and non-asthmatis there were statistically significant differences between them especially among patients with duration of therapy of less than 10 years with a p-values of $(0.001)$ in favour of asthmatics over non-asthmatics and to a lesser extent in those with duration of therapy of more than 15 years. On the other hand, the results of those who developed osteopenia in both groups indicate a statistically significant differences between them especially among those in the shorter duration of therapy i.e. less than 10 years, in favour of asthmatics over non-asthmatics with $p$ value of $(0.000)$. These results indicate that asthma per se may add to the factors which increase the liability of the development of osteopenia and osteoporosis.

Patients with asthma who take inhaled steroid only as in Table 4 were analyzed by ANOVA test and Duncan test according to the dose (in $\mathrm{mg}$ ) and the duration of therapy in years. These analyses demonstrate that patients who take higher doses of inhaled steroids were those who developed osteoporosis with clearly defined statistically significant difference between those who developed osteopenia or osteoporosis with $p$-value of (0.001). The comparison between those who developed osteoporosis and those with negative effect in their bone demonstrate a less statistically 
significant difference between them with $p$-value of (0.008). The duration of therapy did not show any significant effect.

Dual-energy x-ray absorptiometry scan results are typically reported as T-scores (or the number of standard deviations above or below the mean bone mineral density of young healthy adults) whereas the Z-score reflects a value compared to patients matched for age and sex. We compare the DEXA scan score values of asthmatics and non-asthmatics (the $T$-scores and Z-score values) in the entire sample in this study.
Table 5. T-score and Z-score values in asthmatics and non-asthmatics.

\begin{tabular}{|c|c|c|c|}
\hline $\begin{array}{l}\text { DEXA } \\
\text { Scores }\end{array}$ & 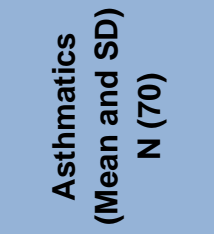 & 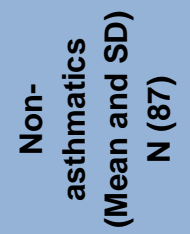 & $\begin{array}{c}\text { P. } \\
\text { value }\end{array}$ \\
\hline $\begin{array}{c}\text { T- } \\
\text { scores }\end{array}$ & $-1.91 \pm(-1.19)$ & $-0.78 \pm(1.55)$ & 0.000 \\
\hline $\begin{array}{c}\text { Z- } \\
\text { score }\end{array}$ & $-1.44 \pm(-2.02)$ & $-0.22 \pm(1.52)$ & 0.000 \\
\hline
\end{tabular}

Table 3. The effect of duration of therapy and its effect on the development of osteopenia and osteoporosis among asthmatics and non-asthmatics.

\begin{tabular}{|l|c|c|c|c|c|c|}
\hline Duration in years & $\begin{array}{c}\text { Asthmatics } \\
\text { Osteoporotic } \\
\text { No. (\%) }\end{array}$ & $\begin{array}{c}\text { Non-asthmatics } \\
\text { Osteoporotic } \\
\text { No. (\%) }\end{array}$ & P-value & $\begin{array}{c}\text { Asthmatics } \\
\text { Osteopenia } \\
\text { No. (\%) }\end{array}$ & $\begin{array}{c}\text { Non-asthmatics } \\
\text { Osteopenia } \\
\text { No. (\%) }\end{array}$ & P-value \\
\hline$<10$ years & $7(36.8)$ & $10(100.0)$ & 0.001 & $9(32.1)$ & $17(89.5)$ & 0.000 \\
\hline $10-14$ years & $3(15.8)$ & $0(0.0)$ & 0.265 & $9(32.1)$ & $1(5.3)$ & 0.027 \\
\hline$\geq 15$ years & $9(47.4)$ & $(0.0)$ & 0.009 & $10(35.7)$ & $1(5.3)$ & 0.016 \\
\hline Total & $19(100.0)$ & $10(100.0)$ & 0.005 & $28(100.0)$ & $19(100.0)$ & 0.001 \\
\hline
\end{tabular}

Table 4. Asthmatics patients on inhalation steriods with osteopenia or osteoporosis in relation to the doses of inhaled steroid.

\begin{tabular}{|l|c|c|c|c|}
\hline Dose and duration & $\begin{array}{c}\text { Osteoporosis } \\
\text { (Mean and SD) } \\
\text { No. (16) }\end{array}$ & $\begin{array}{c}\text { Ostiopenia } \\
\text { (Mean and SD) } \\
\text { No. (23) }\end{array}$ & $\begin{array}{c}\text { None } \\
\text { (Mean and SD) } \\
\text { No. (10) }\end{array}$ & P-value \\
\hline Dose & $0.63 \pm(0.15)$ & $0.5 \pm(0.10)$ & $0.51 \pm(0.12)$ & 0.003 \\
\hline Duration in years & $13.31 \pm(7.97)$ & $13.39 \pm(8.41)$ & $11.42 \pm(10.3)$ & 0.790 \\
\hline
\end{tabular}

As seen in Table 5 there were statistically significant differences between asthmatics and non-asthmatics (including the controls) with $\mathrm{p}$ value for the T-scores and Z-score of $(0.000$, 0.000 ) respectively. These results confirm that asthma is an independent risk factor for the development of osteopenia and osteoporosis.

\section{DISCUSSION}

Corticosteroids enhance bone resorption and decrease bone formation through their action on osteoblasts and osteoclasts and indirectly by inhibiting calcium absorption. As stated early in the introduction, men with chronic lung disease lose bone mass, regardless of whether they were taking corticosteroids or not, which indicates that chronic lung disease, is an independent risk factor for osteoporosis. ${ }^{(4)}$ Asthmatics like COPD share multiple chemoattractants and inflammatory markers like interleukin (IL)-6, TNF- $\alpha$ receptors, acute phase proteins such as $\mathrm{C}$-reactive protein and fibrinogen. These biochemical substances take part in the pathogenesis of osteoporosis.

This study indicates that there was no statistically significant effect of the weight of the patients on the development of osteopenia or osteoporosis; these findings are expected as weight loss of greater than $10 \%$ of total body weight is a predisposing factor for osteoporosis. $^{(8,9)}$

In this study patients on steroid (both asthmatic and non-asthmatics), who developed osteoporosis and liability to fracture of their bones, there were no statistically significant differences between them. DXA is recommended for patients who have been exposed to systemic corticosteroid therapy 
for three months or longer because systemic corticosteroid therapy is independent risk factor for osteoporosis. ${ }^{(10)}$ While the results of those who developed osteopenia in both groups indicated a statistically significant difference between asthmatics and non-asthmatics especially among those who take smaller doses in favour of asthmatics over non-asthmatics.

It is known that DXA is recommended for asthmatic adults who require corticosteroid therapy dose with a systemic potency equal to or exceeding that of $1.0 \mathrm{mg}$ BDP per day. ${ }^{(11)}$ Furthermore, in another study marked adrenal suppression occurs even in patients who take inhaled corticosteroid doses between 0.75 -1.5 $\mathrm{mg} / \mathrm{d} .{ }^{(12)}$

Our results may indicate that asthma per se may add to the factors which increase the liability of the development of osteopenia.

Furthermore, the analysis of data of patients who developed osteopenia among asthmatics and non-asthmatics in relation to the duration of steroid therapy, indicates a statistically significant differences between them, especially so among those in the shorter duration of therapy in favour of asthmatics over non-asthmatics. The above results affirm the high possibility of asthma as part of chronic lung disease spectrum is independent predisposing cause of osteoporosis and osteopenia. Therefore it has been said that "It would be prudent to consider men with chronic lung disease for bone densitometry screening even if they are not treated with corticosteroids". (1)

Patients with asthma who only take inhaled steroid in our study were analyzed according to the dose of inhaled steroid and the duration of therapy. We found that patients who take higher dose of inhaled steroids were those who developed osteoporosis with clearly defined statistically significant difference between those who developed osteopenia or osteoporosis. This finding is in accord with other studies as they found that users of inhaled glucocorticoids had a higher risk of fracture. ${ }^{(13)}$

The $T$ score is a standard deviation compared with a young adult sex-matched control population, while the $Z$ score is a standard deviation compared with an age-and sex-matched control population. The $T$ score between -1.0 and -2.5 defines osteopenia in the WHO classification, recognizing that fracture risk is a continuum event value. ${ }^{(14)}$

We compare the DEXA scan score values (Tscores and Z-score values) of asthmatics and non-asthmatics in the entire sample in this study. There were statistically significant differences in the $T$-score and Z-score values between asthmatics and non-asthmatics (including the controls) in favour of asthmatics over nonasthmatics; these results confirm that asthma is independent risk factor for the development of osteopenia and osteoporosis. From the above results with significant differences between asthmatic and non-asthmatics, we can say and recommend that asthma should be regarded as independent risk factor for the development of osteopenia and osteoporosis. Intake of adequate vitamin $\mathrm{D}$ supplement as preventive measures is highly recommended, as vitamin $D$ is well recognized factor in osteoporosis and osteopenia of all causes. ${ }^{(15-17)}$

\section{REFERENCES}

1. Bono CM, Einhorn TA. Overview of osteoporosis: pathophysiology and determinants of bone strength. Eur Spine J. Oct 2003; 12 Suppl 2: S90-6.

2. Pluskiewicz W, Rogala E. Secondary osteoporosis in patients with steroid-dependent asthma. Przegl Lek. 1997;54(1): 21-4.

3. leda $Y$, Nagasaka $Y$. Inhaled corticosteroids induced osteoporosis in respiratory diseases. Clin Calcium. 2007;17(6):955-62.

4. Iqbal F, Michaelson J, Thaler L, et al. Declining bone mass in men with chronic pulmonary disease: contribution of glucocorticoid treatment, body mass index, and gonadal function. Chest 1999;116: 1616-1624.

5. Raisz LG. Pathogenesis of osteoporosis: concepts, conflicts, and prospects. J Clin Invest. Dec 2005; 115(12):3318-25.

6. Kanis JA, McCloskey EV, Johansson $H$, Oden A, Melton LJ, Khaltaev N. A reference standard for the description of osteoporosis. Bone 2008;42(3):46775.

7. Riggs $\mathrm{BL}$. The mechanisms of estrogen regulation of bone resorption. J. Clin. Invest. 2000; 106: 12031204.

8. Rico H, Revilla M, Villa LF, Hernandez ER, Fernandez JP. Crush fracture syndrome in senile osteoporosis: a nutritional consequence? J Bone Miner Res 1992; 7: 317-9.

9. Edelstein SL, Barrett-Connor E. Relation between body size and bone mineral density in elderly men and women. Am J Epidemiol 1993; 138:160-9 . 
10. Brown JP, Josse RG. For the Scientific Advisory Council of the Osteoporosis Society of Canada: The 2002 clinical practice guidelines for the diagnosis and management of osteoporosis in Canada. Can Med Assoc J 2002;(167 Suppl):S134.

11. Boulet L-P, Becker A, Bérubé D, et al. Canadian asthma consensus report, 1999. Can Med Assoc J 1999; (161 Suppl):S1-61.

12. Brian J. Lipworth, MD, FRCPE Systemic Adverse Effects of Inhaled Corticosteroid Therapy. Arch Intern Med. 1999;159:941-955.

13. Weldon $D$. The effects of corticosteroids on bone growth and bone density. Ann Allergy Asthma Immunol 2009; 103:3-11.
14. Miller PD. Bone mineral density: clinical use and application. Endocrinol Metab Clin North Am. 2003; 32(1):159-179.

15. Jorgensen N, Schwarz P. Osteoporosis in chronic obstructive pulmonary disease patients. Curr Opin Pulm Med. 2008; 14(2): 122-127.

16. Stone AC, Nici L. Other systemic manifestations of chronic obstructive pulmonary disease. Clin Chest Med. 2007; 28(3):553-557.

17. Pacifici R. Estrogen, cytokines, and pathogenesis of postmenopausal osteoporosis. J. Bone Miner. Res. 1996; 11: 1043-1051. 